\title{
KARAKTERISTIK KERUPUK PANGGANG IKAN LELE (Clarias gariepinus) DARI BEBERAPA PERBANDINGAN DAGING IKAN DAN TEPUNG TAPIOKA
}

\section{Characteristics of Grilled Fish Crackers from Several Ratios of Catfish (Clarias gariepinus) Meat and Tapioca Flour}

\author{
Theresia Dwi Suryaningrum ${ }^{1 *}$, Diah Ikasari', Supriyadi ${ }^{2}$, Inti Mulya ${ }^{2}$ dan Agus Heri Purnomo' \\ ${ }^{1}$ Pusat Penelitian dan Pengembangan Daya Saing Produk dan Bioteknologi Kelautan dan Perikanan, \\ JI. KS Tubun Petamburan VI, Jakarta Pusat, Indonesia \\ ${ }^{2}$ Fakultas Teknologi Pertanian, Universitas Gadjah Mada, \\ JI. Flora No. 1, Sleman, DI Yogyakarta, Indonesia \\ Korespondensi Penulis : tdwisuryaningrum@yahoo.com
}

Diterima: 12 Januari 2016; Disetujui: 11 April 2016

\begin{abstract}
ABSTRAK
Penelitian ini bertujuan untuk mempelajari karakteristik kerupuk panggang dari ikan lele (Clarias gariepinus) yang diolah dengan perbandingan daging ikan dan tepung tapioka yaitu $L 1=20: 100$, $\mathrm{L} 2=30: 100$ dan $\mathrm{L} 3=40: 100$ (b/b) dengan 3 kali ulangan. Kerupuk diolah melalui tahapan pengadukan adonan, pencetakan, pengukusan, pengirisan, pengeringan, penggilingan menjadi butiran dan pemanggangan. Kerupuk dipanggang menggunakan alat pemanggang kerupuk berupa moulding yang terbuat dari plat besi berbentuk bulat dengan diameter $7,5 \mathrm{~cm}$, ketebalan $1 \mathrm{~cm}$, yang dilengkapi dengan sistem pemanasan. Butiran kerupuk dimasukkan ke dalam moulder, kemudian ditutup dan dipanggang pada suhu $200 \pm 3{ }^{\circ} \mathrm{C}$ selama \pm 13 detik. Ketika moulder dibuka maka kerupuk akan mengembang. Pengamatan kerupuk panggang dilakukan terhadap analisis proksimat, aktivitas air $\left(\mathrm{a}_{\mathrm{w}}\right)$, pengembangan volume, profil tekstur, warna, struktur mikroskopis serta uji sensori. Hasil penelitian menunjukkan bahwa semakin besar proporsi daging lele berpengaruh nyata terhadap peningkatan nilai gizi (kadar protein dan lemak) namun peningkatan sifat sensori seperti aroma, kerenyahan dan rasa kerupuk panggang pada proposi daging lele $30 \%$ tidak berbeda dengan $40 \%$. Sebaliknya semakin besar proporsi daging lele yang digunakan berpengaruh terhadap menurunnya kadar air, nilai $a_{w}$ dan kecerahan kerupuk yang dihasilkan. Perbandingan daging ikan lele dan tepung tapioka sebesar 30:100 (b/b) merupakan rasio perbandingan yang dapat menghasilkan kualitas kerupuk panggang terbaik dengan kadar protein sebesar $6,79 \pm 0,54 \%$, kadar lemak sebesar $5,99 \pm 1,04 \%$, pengembangan volume sebesar $886,21 \pm 67,81 \%$, kerenyahan sebesar $11,51 \pm 3,28 \mathrm{~N}$ dan warna dengan nilai tingkat kecerahan $\left(L^{*}\right)$ sebesar $82,62 \pm 0,20$, kemerahan $\left(a^{*}\right)$ $5,01 \pm 0,20$ dan kekuningan $\left(b^{\star}\right) 20,37 \pm 0,50$, dengan aroma, rasa dan kerenyahan paling disukai oleh panelis.
\end{abstract}

KATA KUNCl: $\quad$ kerupuk panggang, nilai gizi, Clarias gariepinus, uji sensori

\section{ABSTRACT}

The research aims to study the characteristics of grilled catfish (Clarias gariepinus) crackers processed with various ratios of fish meat and flour. Comparison of catfish meat and tapioca flour $(w / w)$ consists of three levels; $L 1=(20: 100) L 2=,(30: 100)$ and $L 3=(40: 100)$ with 3 replications. Crackers were processed by mixing the dough, followed by molding, steaming, slicing, drying, then grinding into granules (gritf) and then finally grilled. The crackers was using a moulder, a round-shaped moulder with a diameter $7.5 \mathrm{~cm}$ and a thickness of $1 \mathrm{~cm}$, equipped with a heating system. Granulated crackers was put into the chamber, then grilled at temperature of $200 \pm 3{ }^{\circ} \mathrm{C}$ for \pm 13 seconds. Once the moulder chamber was opened, crackers will expand masively. Assessment was done on proximate analysis, water activity $\left(a_{w}\right)$, volume expansion, texture profile, colour, microscopic structure and sensory evaluation. The results showed that higher proportion of fish meat increased the nutritional value (fat and protein content), however the increase of sensory properties such as aroma, crispiness, and flavour in the meat proportion of $30 \%$ and $40 \%$ was not different. Conversely, higher proportion of meat decreased the moisture content, $a_{w}$ value and brightness, of grilled crackers. Based on the quality parameters, the crackers with the ratios of meat and tapioca flour $(w / w)$ of $30: 100$ produced the best product which had protein content of $6.79 \pm 0.54 \%$, fat content of $5.99 \pm 1.04 \%$, volume expansion of $886.21 \pm 67.81 \%$, crispiness of $11.51 \pm 3.28 \mathrm{~N}$ and color with a value of the brightness $\left(L^{*}\right)$ of $82.62 \pm 0.20$, redness $\left(a^{*}\right) 5.01 \pm 0.20$ and yellowness $\left(b^{*}\right) 20.37 \pm 0.50$. This treatment also produced most preferred aroma, flavour and crispiness at product by the panelists.

KEYWORDS: grilled crackers, nutritional value, Clarias gariepinus, sensory evaluation 


\section{PENDAHULUAN}

Kerupuk ikan merupakan makanan ringan yang dibuat dari daging lumat ikan dan tepung tapioka yang diolah dengan cara pengadukan adonan, pencetakan, pengukusan, pengirisan, pengeringan dan penggorengan. Teksturnya yang renyah serta rasanya yang enak dan gurih menyebabkan kerupuk ikan sangat digemari masyarakat. Pada umumnya kerupuk matang yang dijual di pasaran adalah kerupuk yang digoreng dengan menggunakan minyak. Proses penggorengan ini dapat meningkatkan kadar lemak kerupuk hingga 13\% (Koswara, 2009) karena banyaknya minyak yang terperangkap dalam pori pori kerupuk. Hasil penelitian Neiva et al.(2011) menyebutkan bahwa kerupuk ikan yang digoreng mengandung lemak yang cukup tinggi yaitu $26,11 \pm 0,5 \%$, sedangkan kerupuk yang dipanggang dengan microwave selama 60 detik kandungan lemaknya hanya sebesar $0,42 \pm 0,07 \%$. Proses penggorengan dapat menyebabkan terbentuknya asam lemak trans (Sartika, 2009). Oleh karena itu kerupuk panggang dipandang lebih aman bagi kesehatan dibanding dengan kerupuk yang digoreng.

Berbagai pemasakan kerupuk panggang telah dilakukan oleh pengolah kerupuk aci/kerupuk mlarat di Cirebon yang dipanaskan dengan menggunakan medium pasir. Hasil penelitian Siswantoro (2009) menunjukkan bahwa pemasakan kerupuk dengan menggunakan pasir pada suhu $180^{\circ} \mathrm{C}$ menghasilkan pengembangan kerupuk $459 \%$, dan pada $240{ }^{\circ} \mathrm{C}$ diperoleh pengembangan $725 \%$. Di Bengkulu, Sumatera Selatan, Lampung dan Bangka, pengolahan kerupuk panggang dilakukan dengan perbandingan ikan dan tapioka 1:1 dan pemanggangan kerupuk dilakukan di atas bara api. Kerupuk yang diperoleh dari hasil pemanggangan tersebut memiliki tekstur yang keras, permukaan kurang rapi dan warna tidak merata antara coklat muda dan kuning kecoklatan.

Pemanasan kerupuk dapat dilakukan dengan menggunakan alat pemanggang kerupuk dalam suatu moulder yang terbuat dari plat baja berbentuk bulat yang dilengkapi dengan sistem pemanas. Alat tersebut telah banyak di display di supermaket untuk memanggang kerupuk udang. Kerupuk yang akan dipanggang dihancurkan terlebih dahulu sehingga menjadi butiran kerupuk, kemudian dimasukkan ke dalam moulder yang telah dipanaskan pada suhu $\pm 200{ }^{\circ} \mathrm{C}$. Plat kemudian ditutup dan pemanasan dilakukan selama 10-15 detik. Ketika plat dibuka kerupuk akan mengembang. Kerupuk yang dihasilkan dari alat ini bentuknya bulat, rapi, warna rata, kenampakan lebih cemerlang, tekstur sangat renyah serta rasanya lebih enak dari kerupuk panggang biasa.
Pada prinsipnya proses pemanasan bertujuan untuk mengembangkan kerupuk sehingga teksturnya renyah. Pemanasan pada suhu tinggi menyebabkan molekul air yang terikat pada kerupuk mentah menguap dan menghasilkan tekanan uap yang mengembangkan kerupuk (Koswara, 2009). Keuntungan pemasakan kerupuk dengan menggunakan moulder adalah kerupuk tidak berminyak, volume pengembangan kerupuk lebih besar sehingga teksturnya lebih renyah dan rasa kerupuk lebih enak.

Pengembangan kerupuk juga dipengaruhi oleh perbandingan antara ikan dan pati yang digunakan. Perbandingan pati dan ikan akan mempengaruhi pola migrasi air di dalam adonan selama proses gelatinisasi yang dapat berpengaruh terhadap pengembangan kerupuk (Hadi, 2001). Pengembangan kerupuk mencapai tingkat tertinggi bila gelatinisasi pati terjadi secara sempurna karena granula pati dapat mengembang secara penuh (Kyaw, Yu, Cheow \& Dzulkifly, 1999). Menurut Ibrahim, Dewi dan Sumardianto (2003) pengembangan kerupuk ikan selain dipengaruhi proporsi jumlah ikan dan tepung yang digunakan, juga dipengaruhi oleh mutu tepung tapioka yang digunakan, jenis dan jumlah bahan pengembang, homogenitas adonan, ketebalan irisan, tingkat kekeringan kerupuk, serta suhu penggorengan. Hasil penelitian Nurul, Boni dan Noryati (2009) mengenai perbandingan yang berbeda antara ikan patin dan tapioka menunjukkan bahwa semakin banyak ikan yang digunakan maka pengembangan kerupuk semakin kecil, sebaliknya semakin sedikit ikan yang digunakan diperoleh kerupuk yang mengembang tetapi kerupuk sangat berpori dengan permukaan yang tidak merata. Perbandingan ikan dan tapioka 1:1 menghasilkan kerupuk dengan tingkat pengembangan dan kerenyahan paling baik dibandingkan dengan perlakuan lainnya. Penelitian kerupuk panggang yang telah dilakukan oleh Suryaningrum, Peranginangin, Irianto, Muljanah dan Syamdidi (2013) dengan menggunakan metode Placket Burman menunjukkan bahwa faktor-faktor yang mempengaruhi pengembangan kerupuk panggang adalah ikan, rumput laut, gula dan lama proses pengadukan.

Kerupuk ikan idealnya diolah dengan menggunakan ikan laut yang mempunyai flavor kuat, daging tebal, warna putih serta rasa yang enak, seperti ikan tenggiri (Scomberomorus sp.), ikan kakap (Lutjanus sp.), tongkol (Euthynnus sp.) dan manyung (Arius sp.). Namun pada dasarnya semua jenis ikan dapat digunakan sebagai bahan baku kerupuk. Beberapa jenis ikan yang dapat digunakan 
sebagai bahan kerupuk antara lain ikan mata belok (Brachydeuterus auritus) (King, 2002), remang (Congresox talabon), kakap merah (Lates calcarifer), dan belida (Notopterus chilatus) (Peranginangin, Fawzya, Sugiyono \& Muljanah, 1997), ikan gabus (Ophiocephalus striatus) (Setiawan, Sulistiyati \& Suprayitno, 2013), bandeng (Chanos chanos) (Wijaya, 2011), belut (Monopterus albus) (Yulistiani, Jariah \& Siswoyo, 2004). Berkembangnya budidaya lele yang cukup pesat di beberapa daerah, berpotensi untuk menjadikan ikan lele sebagai bahan baku kerupuk. Protein lele mengandung asam amino esensial seperti isoleusin, leusin, lisin, fenilalanin, dan glutamat dalam jumlah yang cukup, bahkan kandungannya lebih tinggi dibandingkan dengan standar asam amino esensial yang dikeluarkan oleh FAO untuk kebutuhan tubuh (FAO, 1985 dalam Astawan 2009). Kerupuk lele mempunyai cita rasa yang enak dan gurih, dibandingkan kerupuk ikan air tawar lainnya. Hal ini juga ditunjukkan dari hasil penelitian Okereke dan Onunkwo (2014), terhadap kerupuk yang diolah dari ikan patin (catfish) yang mempunyai rasa lebih gurih dibandingkan dengan kerupuk yang diolah dari ikan mas. Hasil penelitian Ikasari dan Muljanah (2014) tentang kerupuk panggang yang diolah dengan perbandingan ikan lele dan tapioka (1:1) yang diformulasi dengan rumput laut 2,4 , dan $6 \%$ serta telur 10,15 , dan $20 \%$ menghasilkan formulasi kerupuk terbaik yaitu formula yang menggunakan rumput laut $2 \%$ dan telur $10 \%$. Kerupuk tersebut mempunyai daya kembang $276 \%$ dan tingkat kerenyahan terbaik dengan skor 5,75 dari 7. Namun demikian kerupuk yang dihasilkan masih memiliki tingkat pengembangan yang rendah, serta tekstur yang kurang renyah bila dibandingkan dengan kerupuk udang yang dipanggang dengan cara yang sama. Oleh karena itu dalam penelitian ini akan dipelajari pengaruh perbandingan tapioka dan daging lumat ikan lele dalam pembuatan kerupuk panggang terhadap nilai gizi, daya kembang, tekstur, kerenyahan, sifat mikroskopis dan sifat sensori kerupuk panggang yang dihasilkan.

\section{BAHAN DAN METODE}

\section{Bahan}

Bahan yang digunakan dalam penelitian ini adalah ikan lele (Clarias gariepenus) hidup yang diperoleh dari Parung, Bogor dengan berat rata-rata 0,89 $\pm 0,21$ $\mathrm{kg}$ per ekor. Bahan lain yang digunakan adalah tepung tapioka merk "Athena" yang diperoleh dari pengolah kerupuk di Kelapa Gading Jakarta, garam, gula, pasta rumput laut, baking powder, telur, minyak sawit, dan bahan kimia untuk analisis. Pasta rumput laut diolah dari rumput laut Eucheuma cottonii kering tawar yang telah direndam semalam dan dikukus selama 15 menit, kemudian dihancurkan.

\section{Metode}

Ikan lele dimatikan dengan metode shock suhu rendah, yaitu ikan dimatikan di dalam cool box yang telah diisi air es (suhu $\pm 5^{\circ} \mathrm{C}$ ) selama 10-15 menit. Ikan kemudian dipotong dan dilakukan pendarahan, lalu difilet dan dicuci dengan menggunakan air dingin. Filet ikan kemudian digiling 2 kali sehingga diperoleh daging lumat yang lembut, yang selanjutnya digunakan sebagai bahan baku kerupuk.

Perlakuan yang digunakan dalam penelitian ini adalah perbandingan daging lele lumat dan tepung tapioka yang terdiri dari 3 level sebagai berikut

L1 = Perbandingan ikan : tepung adalah 20:100 (daging ikan lele $20 \% \mathrm{~b} / \mathrm{b}$ tepung tapioka)

L2 = Perbandingan ikan : tepung adalah 30:100 (daging ikan lele $30 \% \mathrm{~b} / \mathrm{b}$ tepung tapioka)

L3 = Perbandingan ikan : tepung adalah 40:100 (daging ikan lele $40 \% \mathrm{~b} / \mathrm{b}$ tepung tapioka)

Masing masing perlakuan diulang sebanyak 3 kali. Formulasi kerupuk didasarkan pada penelitian yang dilakukan oleh Ikasari dan Muljanah (2014) sehingga diperoleh komposisi adonan seperti pada Tabel 1.

Pembuatan kerupuk dilakukan dengan mencampurkan dalam mesin pengaduk (mixing and kneading machine) dan diaduk selama \pm 30 menit sehingga homogen. Adonan dibentuk menjadi bulat panjang secara manual dengan panjang $10-15 \mathrm{~cm}$ dan diameter $4-5 \mathrm{~cm}$, kemudian dikukus selama 45 menit. Setelah proses pengukusan, lenjeran kerupuk didinginkan pada suhu ruang $\left(26 \pm 2{ }^{\circ} \mathrm{C}\right)$ selama semalam kemudian diiris dengan tebal irisan $\pm 2 \mathrm{~mm}$. Potongan kerupuk kemudian diatur di atas loyang penjemur dan dijemur di bawah sinar matahari terik selama 2 hari hingga kering atau kerupuk mudah dipatahkan. Kerupuk mentah yang telah kering digiling dengan mesin penggiling tanpa penyaringan/ pengayakan hingga menjadi kepingan/butiran kerupuk yang kasar (grits) dengan diameter 1-3 mm.

Kerupuk mentah giling dipanggang pada alat pemanas dalam moulder yang terbuat dari pelat besi berbentuk bulat dengan diameter $7,5 \mathrm{~cm}$ dan ketebalan $1 \mathrm{~cm}$ yang dilengkapi dengan sistem pemanas. Suhu pemanas dalam moulder diatur sehingga mencapai suhu $200 \pm 3{ }^{\circ} \mathrm{C}$. Setelah suhu tercapai, kepingan/butiran kerupuk $( \pm 16 \mathrm{~g})$ 
Tabel 1. Komposisi bahan kerupuk panggang yang diolah dengan berbagai perbandingan ikan lele dan tapioka Table 1. Ingredient composition of grilled crackers processed with various proportions of catfish and tapioca

\begin{tabular}{lcccccccc}
\hline \multirow{2}{*}{ Bahan/Ingredient } & (\%) & \multicolumn{2}{c}{ L1 (20:100) } & \multicolumn{2}{c}{ L2 (30:100) } & \multicolumn{2}{c}{ L3 (40:100) } \\
\cline { 3 - 9 } & ${ }^{* *}$ & Gram & (\%) $^{*}$ & Gram & (\%) $^{*}$ & Gram & $(\%)^{*}$ \\
\hline Tepung tapioka/Tapioca flour & 100 & 3000 & 68.73 & 3000 & 60.42 & 3000 & 53.91 \\
Daging lele lumat/Minced catfish & $* * *$ & 600 & 13.75 & 1200 & 24.17 & 1800 & 32.34 \\
Pasta rumput laut/Seaweed paste & 2 & 60 & 1.37 & 60 & 1.21 & 60 & 1.08 \\
Telur/Egg & 10 & 300 & 6.87 & 300 & 6.04 & 300 & 5.39 \\
Gula/Sugar & 5 & 150 & 3.44 & 150 & 3.02 & 150 & 2.69 \\
Baking powder & 1 & 30 & 0.69 & 30 & 0.61 & 30 & 0.54 \\
Garam/Salt & 4 & 120 & 2.75 & 120 & 2.42 & 120 & 2.16 \\
Monosodium Glutamat & 0.5 & 15 & 0.34 & 15 & 0.30 & 15 & 0.27 \\
Minyak sayur/Vegetable oil & 3 & 90 & 2.06 & 90 & 1.81 & 90 & 1.62 \\
\hline & 125.5 & 4365 & 100 & 4965 & 100 & 5565 & 100 \\
\hline
\end{tabular}

Keterangan/Note:

* persentase dari seluruh adonan pada setiap perlakuan/percentage of dough in each treatment

** persentase seluruh bahan berdasarkan $\mathrm{b} / \mathrm{b}$ tepung tapioka/percentage of all material based on $w / w$ tapioca flour

${ }^{* * *}$ persentase daging ikan lele disesuaikan dengan perlakuan/catfish meat percentage adjusted for the treatment

dimasukkan ke dalam moulder hingga permukaan rata. Moulder kemudian ditutup dan pemanasan dilakukan selama \pm 13 detik dan ketika moulder dibuka maka kerupuk akan mengembang.

Karakteristik mutu kerupuk ikan lele panggang diamati terhadap analisis proksimat (BSN, 2006) yang meliputi kadar air, kadar abu, kadar protein, kadar lemak, dan karbohidrat menggunakan metode by difference. Aktivitas air $\left(\mathrm{a}_{w}\right)$ dianalisis dengan menggunakan alat $\mathrm{a}_{w}$ meter TH 500 Novasina. Analisis fisik diamati terhadap tingkat kekerasan dan kerenyahan kerupuk yang diukur dengan menggunakan Stable Micro Systems Texture Analyzer XT Plus dengan load cell capacity $5 \mathrm{k}$ (Huda, Ismail, Leng \& Yee, 2010), dan pengembangan volume diukur dengan menggunakan metode pengembangan volume (Yu, 1993). Warna kerupuk dianalisis dengan menggunakan color flex $E Z$ HunterLab. Nilai $L=100$ untuk warna putih dan nilai $L=0$ untuk warna hitam, +a untuk warna kemerahan, -a untuk warna kehijauan, $+b$ untuk warna kekuningan dan -b untuk warna biru (Anon., 2015). Tekstur kerupuk secara mikroskopis diamati dengan menggunakan Scanning Electron Microscopy JCM-6000 (Kyaw, Yu,Cheow, \& Dzulkifly, 2001). Analisis sensori terhadap kesukaan dilakukan dengan menggunakan uji hedonik (SNI 01.2346-2006, BSN 2006) dengan rentang nilai 1-7 terhadap kenampakan, warna, bau dan kesukaan keseluruhan kerupuk mentah, sedangkan pada kerupuk panggang pengamatan ditambah dengan tingkat kerenyahan dan rasa. Panelis yang melakukan pengujian adalah panelis terlatih dari Laboratorium Sensori Pusat Penelitian dan Pengembangan Daya Saing Produk dan Bioteknologi Kelautan dan Perikanan Jakarta sebanyak 20 orang. Rancangan percobaan yang digunakan adalah Rancangan Acak Lengkap dengan 3 kali ulangan. Data diolah secara statistik dengan menggunakan software Statistical Package for Social Science (SPSS) versi 16.0.

Penentuan perlakuan terbaik dilakukan berdasarkan nilai kumulatif dari setiap nilai pengujian yang telah dikonversikan menjadi 3 kelompok nilai (pembobotan). Nilai 3 sebagai nilai mutu tertinggi, nilai 1 sebagai nilai mutu terendah dan nilai 2 adalah nilai di antara keduanya. Nilai pengujian yang tidak berbeda nyata diberikan bobot yang sama. Perlakuan dengan total nilai tertinggi ditetapkan sebagai sebagai perlakuan terbaik.

\section{HASIL DAN BAHASAN}

\section{Analisis Proksimat Kerupuk Mentah}

Pengaruh perbandingan daging ikan lele dan tepung tapioka terhadap komposisi kimia kerupuk ikan mentah dapat dilihat pada Tabel 2. Hasil analisis menunjukkan bahwa nilai kadar protein dan kadar lemak kerupuk ikan lele mentah meningkat secara signifikan $(p<0,05)$ serta menurunkan kadar karbohidrat, kadar air dan nilai $a_{w}$ (Tabel 2) sejalan 
Tabel 2. Hasil analisis proksimat dan nilai $\mathrm{a}_{w}$ kerupuk lele mentah

Table 2. Proximate and $a_{w}$ value of raw catfish crackers

\begin{tabular}{|c|c|c|c|c|}
\hline \multirow[b]{2}{*}{$\begin{array}{l}\text { Parameter/ } \\
\text { Parameters }\end{array}$} & \multicolumn{3}{|c|}{ Perlakuan/Treatment } & \multirow{2}{*}{$\begin{array}{c}\text { Standar kerupuk mentah } \\
\text { menurut SNI 01-2713-1999/ } \\
\text { Standard of raw fish crackers } \\
\text { by SNI 01-2713-1999 }\end{array}$} \\
\hline & $\begin{array}{c}\text { L1 } \\
(20: 100)\end{array}$ & $\begin{array}{c}\text { L2 } \\
(30: 100)\end{array}$ & $\begin{array}{l}\text { L3 } \\
(40: 100)\end{array}$ & \\
\hline Kadar air/Moisture content (\%) & $11.86 \pm 0.51^{\mathrm{b}}$ & $10.86 \pm 0.24^{a}$ & $10.86 \pm 0.30^{\mathrm{a}}$ & Maks/Max $12 \%$ \\
\hline Kadar protein/Protein content (\%) & $3.68 \pm 0.23^{a}$ & $7.66 \pm 0.37^{b}$ & $8.98 \pm 0.32^{\mathrm{c}}$ & Min/Min 6\% \\
\hline Kadar lemak/Fat content (\%) & $4.58 \pm 0.72^{a}$ & $5.73 \pm 0.95^{b}$ & $6.98 \pm 1.29^{c}$ & Min/Min $0.5 \%$ \\
\hline Kadar abu/Ash content (\%) & $4.37 \pm 0.23^{a}$ & $4.35 \pm 0.03^{\mathrm{a}}$ & $4.42 \pm 0.03^{a}$ & \\
\hline $\begin{array}{l}\text { Kadar karbohidrat/Carbohydrate } \\
\text { content (\%) }\end{array}$ & $75.81 \pm 0.82^{c}$ & $71.56 \pm 1.26^{b}$ & $68.77 \pm 1.05^{\mathrm{a}}$ & - \\
\hline Nilai $\mathrm{a}_{w} / \mathrm{a}_{w}$ value & $0.56 \pm 0.01^{\mathrm{b}}$ & $0.49 \pm 0.01^{a}$ & $0.49 \pm 0.01^{a}$ & - \\
\hline
\end{tabular}

Keterangan: Huruf yang sama pada kolom yang berbeda menyatakan tidak berbeda nyata $(p>0.05)$

Note : Same letters in different columns are not significantly different $(p>0.05)$

dengan meningkatnya perbandingan daging ikan lele yang digunakan. Peningkatan tersebut disebabkan karena daging lele yang digunakan dalam penelitian ini mengandung lemak sebesar $5,27 \%$ dan protein $17,89 \%$. Semakin banyak daging ikan lele yang ditambahkan semakin meningkat kadar lemak dan protein kerupuk mentah yang dihasilkan. Hasil ini sejalan dengan hasil penelitian Nurul et al. (2009) terhadap kerupuk ikan patin yang diolah dengan berbagai perbadingan ikan dan tapioka yang menunjukkan bahwa peningkatan proporsi ikan dapat meningkatkan kadar protein dan kadar lemak serta menurunkan kadar karbohidrat pada kerupuk yang dihasilkan.

Nilai kadar air pada semua perlakuan rasio daging ikan lele dan tepung tapioka (Tabel 2) telah memenuhi standar kerupuk mentah menurut SNI 01-2713-1999 (maksimal 12\%) maupun kadar air kerupuk komersial yang berkisar antara 9-13\% (Huda et al., 2010). Pengeringan yang dilakukan dapat menguapkan air bebas maupun air yang terikat sehingga produk mengalami penurunan $\mathrm{a}_{w}$. Hasil analisis menunjukkan nilai $a_{w}$ kerupuk berkisar antara $0,49 \pm 0,01$ sampai $0,56 \pm 0,01$. Nilai $a_{w}$ menggambarkan tingkat keterikatan air pada sistem pangan yang dapat digunakan untuk pertumbuhan mikroorganisme dan aktivitas enzim. Sebagian besar mikroba (bakteri, khamir dan kapang) membutuhkan $a_{w}$ di atas 0,60 untuk melakukan pertumbuhan, sehingga pada $a_{w}$ kerupuk ikan lele mentah yang dihasilkan tidak mudah ditumbuhi oleh mikroba.
Dari hasil penelitian ini kadar protein kerupuk ikan lele mentah yang memenuhi standar SNI 01-27131999 untuk kerupuk ikan (>6\%), adalah perlakuan L2 ${ }_{(30: 100)}$ dan L3 ${ }_{(40: 100)}$ sedangkan pada L1 ${ }_{(20: 100)}$ kadar proteinnya hanya $3,68 \pm 0,23 \%$. Oleh karena itu dalam pengolahan kerupuk panggang jumlah ikan yang digunakan minimum adalah $30 \%$. Kadar lemak kerupuk mentah yang diperoleh dalam penelitian ini lebih besar dari 0,5\% (standar minimal lemak kerupuk mentah menurut SNI 01-2713-1999). Kadar lemak yang terlalu tinggi ini dapat berpengaruh terhadap daya awet kerupuk mentah yang dihasilkan.

Kerupuk yang dihasilkan dalam penelitian ini memiliki kadar abu berkisar 4,35-4,42\%, sedangkan SNI. 01-2713-1999 mensyaratkan kadar abu tanpa garam yang diijinkan adalah sebesar $1 \%$. Kadar abu dari kerupuk yang dihasilkan dalam penelitian ini belum menggambarkan kadar abu tanpa garam sehingga belum dapat dipastikan apakah kerupuk tersebut telah memenuhi persyaratan SNI. 01-2713-1999.

\section{Sifat Kimia dan Fisik Kerupuk Panggang}

Kadar air kerupuk panggang yang diperoleh dalam penelitian ini berkisar antara 2,15 $\pm 0,16 \%$ sampai $2,55 \pm 0,11 \%$. Peningkatan proporsi ikan berpengaruh terhadap penurunan kadar air dan nilai $a_{w}$ kerupuk panggang secara nyata $(p<0,05)$. Semakin banyak jumlah ikan yang ditambahkan semakin rendah kadar air kerupuk panggang yang dihasilkan. Hal ini dapat dikaitkan dengan kadar air kerupuk mentah yang 
dihasilkan, yaitu semakin banyak jumlah ikan yang ditambahkan semakin rendah kadar air kerupuk mentah yang dihasilkan (Tabel 2). Ketika kerupuk dipanggang dengan suhu dan waktu pemanasan yang sama (suhu $200 \pm 3^{\circ} \mathrm{C}$, waktu 13 detik), maka kerupuk yang diolah dengan menggunakan proporsi ikan yang lebih banyak, kadar airnya lebih rendah.

Terlihat adanya hubungan kadar air dengan aktivitas air $\left(a_{w}\right)$. Semakin rendah kadar air maka semakin rendah pula nilai $a_{w}$ nya. Pemanasan berakibat menurunkan kadar air dan nilai $a_{w}$ kerupuk panggang yang dihasilkan. Seperti halnya kerupuk mentah, peningkatan proporsi jumlah ikan berpengaruh terhadap meningkatnya kadar lemak dan protein serta menurunnya karbohidrat kerupuk panggang yang dihasilkan. Kadar lemak kerupuk panggang dalam penelitian ini berkisar antara 5,01 $\pm 0,15 \%$ sampai $7,50 \pm 0,50 \%$, tidak jauh berbeda dengan kerupuk mentahnya. Kadar lemak kerupuk pada penelitian ini (5,01-7,50\%) jauh lebih rendah dibandingkan dengan kadar lemak kerupuk goreng hasil penelitian Neiva et al. (2011) yang menggunakan daging ikan tenggiri dan tapioka 1:1 yaitu $26,11 \pm 0,54 \%$ (bk), namun lebih tinggi dibandingkan dengan kerupuk panggang yang dimasak dengan microwave yang kadar lemaknya hanya sebesar $0,42 \pm 0,07 \%$ bk.

Pengembangan volume cenderung mengalami penurunan seiring dengan peningkatan proporsi daging ikan lele pada kerupuk (Nurul et al., 2009; Yu, 1991). Namun pengembangan volume tersebut tidak berbeda secara signifikan $(p>0,05)$. Pengembangan volume kerupuk yang diolah dengan cara dipanggang ini cukup tinggi, yaitu berkisar antara $873,23 \pm 50,40 \%$ sampai $937,58 \pm 108,39 \%$, dibandingkan dengan kerupuk panggang hasil penelitian Ikasari dan Muljanah (2009) yang hanya sebesar $276 \%$. Meningkatnya daya kembang kerupuk yang dihasilkan dalam penelitian ini disebabkan karena proporsi jumlah ikan yang digunakan lebih kecil. Dalam penelitian Ikasari dan Muljanah (2014) perbandingan jumlah ikan dan tapioka adalah (1:1), sementara dalam penelitian ini jumlah ikan yang digunakan adalah 20,30 , dan $40 \%$ dari tepung tapioka yang digunakan. Perbandingan ikan dan tepung tapioka berpengaruh terhadap tingkat pengembangan serta kerenyahan kerupuk yang dihasilkan (King, 2002; Ibrahim et al., 2003). Pengembangan kerupuk dapat dihubungkan dengan proses gelatinisasi, apabila adonan kerupuk dapat tergelatinisasi secara sempurna kerupuk dapat mengembang dengan baik (Huda et al., 2010; Kyaw et al., 2001). Daya kembang kerupuk akan semakin berkurang bila persentase ikan lebih banyak dibandingkan dengan tepung tapioka yang digunakan (Kowara, 2009). Menurut Imaningsih (2012), jika adonan yang mengandung protein dan tapioka dipanaskan, maka air akan digunakan terlebih dahulu untuk mendenaturasi protein, sehingga sebelum suhu gelatinisasi tercapai $\left(75-76^{\circ} \mathrm{C}\right)$, air sudah tidak cukup untuk membuat tapioka tergelatinasi secara sempurna. Lebih lanjut dikatakan bahwa gugus hidroksil dari molekul protein akan berinteraksi dengan percabangan dari amilopektin pada tapioka sehingga dapat menghambat ekspansi kerupuk ketika dipanaskan.

Kerupuk panggang yang dihasilkan mengembang cukup besar bila dibandingkan dengan kerupuk goreng

Tabel 3. Komposisi kimia dan sifat fisik kerupuk ikan lele panggang

Table 3. Chemical composition and physical characteristic of grilled fish crackers

\begin{tabular}{lccc}
\hline \multirow{2}{*}{ Parameter/Parameters } & \multicolumn{3}{c}{ Perlakuan/Treatment } \\
\cline { 2 - 4 } & L1 (20:100) & L2 (30:100) & L3 (40:100) \\
\hline Kadar air/Moisture content (\%) & $2.55 \pm 0.11^{\mathrm{c}}$ & $2.35 \pm 0.20^{\mathrm{b}}$ & $2.15 \pm 0.16^{\mathrm{a}}$ \\
Kadar protein/Protein content (\%) & $3.51 \pm 0.27^{\mathrm{a}}$ & $6.79 \pm 0.54^{\mathrm{b}}$ & $8.11 \pm 0.62^{\mathrm{c}}$ \\
Kadar lemak/Fat content (\%) & $5.01 \pm 0.15^{\mathrm{a}}$ & $5.99 \pm 1.04^{\mathrm{b}}$ & $7.50 \pm 0.0^{\mathrm{c}}$ \\
Kadar abu/Ash content (\%) & $4.49 \pm 0.10^{\mathrm{a}}$ & $4.52 \pm 0.12^{\mathrm{a}}$ & $4.46 \pm 0.04^{\mathrm{a}}$ \\
Kadar karbohidrat/Carbohydrate content (\%) & $84.43 \pm 0.26^{\mathrm{c}}$ & $79.96 \pm 1.46^{\mathrm{b}}$ & $77.81 \pm 0.35^{\mathrm{a}}$ \\
Nilai $\mathrm{a}_{\mathrm{w}} / \mathrm{a}_{w}$ value & $0.21 \pm 0,02^{\mathrm{c}}$ & $0.18 \pm 0,02^{\mathrm{b}}$ & $0.16 \pm 0,02^{\mathrm{a}}$ \\
Pengembangan volume/Volume expansion (\%) & $937.58 \pm 108.39^{\mathrm{a}}$ & $886.21 \pm 67.81^{\mathrm{a}}$ & $873.23 \pm 50.40^{\mathrm{a}}$ \\
\hline
\end{tabular}

Keterangan: Huruf yang sama pada kolom yang berbeda menyatakan tidak berbeda nyata $(p>0.05)$ 
yang dihasilkan dari industri kerupuk di Jepara Jawa Tengah, yang berkisar antara 54,48 -134,58\% (Ibrahim et al., 2003). Demikian juga hasil penelitian Huda et al., (2010) terhadap kerupuk komersial yang daya kembangnya setelah digoreng berkisar antara 38$145 \%$. Pengembangan kerupuk yang cukup tinggi pada kerupuk panggang disebabkan karena terjadinya penurunan suhu secara tiba-tiba di dalam moulder dari $200^{\circ} \mathrm{C}$ menjadi $28^{\circ} \mathrm{C}$ ketika moulder dibuka. Perbedaan suhu tersebut mengakibatkan ekspansi uap air yang mengakibatkan kerupuk mengembang cukup tinggi (Gomes \& Aguillera, 1983). Dinyatakan pula bahwa pengembangan volume yang cukup tinggi tersebut berpengaruh terhadap kerenyahan kerupuk panggang yang dihasilkan. Daya kembang dan tekstur kerupuk juga dipengaruhi oleh rasio dari amilosa dan amilopektin pati yang digunakan (Yu,1991). Amilosa cenderung mengurangi daya kembang dan meningkatkan densitas kerupuk, sedangkan amilopektin berfungsi sebaliknya, yaitu meningkatkan daya kembang dan menurunkan densitas kerupuk (Haryadi, 1994).

\section{Warna Kerupuk}

Hasil analisis warna $L^{*} a^{*} b^{*}$ dengan menggunakan chromameterterhadap kerupuk mentah dan panggang disajikan pada Tabel 4. Tingkat kecerahan $\left(L^{*}\right)$ kerupuk mentah ikan lele cenderung mengalami peningkatan yang berfluktuasi, sedangkan tingkat kemerahan $\left(a^{*}\right)$ cenderung mengalami penurunan seiring dengan peningkatan proporsi daging ikan lele dalam kerupuk. Hal ini berlawanan dengan tingkat kekuningan $\left(b^{\star}\right)$, dimana semakin banyak jumlah ikan yang ditambahkan semakin kuning warna kerupuk mentah yang dihasilkan. Menurut Taewee (2011) semakin banyak ikan yang ditambahkan semakin banyak air yang terperangkap di dalam protein yang mengalami perubahan struktur karena terdenaturasi selama pemanasan. Kondisi ini akan menyempurnakan proses gelatinisasi dan adonan lebih cepat matang, serta menghasilkan kerupuk berwarna lebih cerah dan kekuningan. Warna kekuningan berasal dari pigmen karoten pada daging ikan lele. Menurut Lovell (2004) warna kekuningan dari daging ikan berasal dari pakan buatan yang diberikan yang berasal dari jagung yang mengandung beta karoten.

Pada perlakuan $\mathrm{L} 1_{(20: 100}$, proses gelatinisasi yang terjadi kurang sempurna sehingga bagian kristalin pati terlihat lebih gelap dengan bagian tengah yang berwarna keputih-putihan. Hal ini disebabkan karena kurangnya jumlah ikan yang ditambahkan menyebabkan tidak adanya migrasi air dari pinggir menuju ke tengah lenjeran sehingga bagian tengah lenjeran tidak matang pada saat proses pengukusan (Hadi, 2001) yang berakibat warna kerupuk yang dihasilkan kurang cerah. Namun warna kerupuk tersebut mengalami perubahan setelah proses pemanggangan. Peningkatan proporsi daging ikan lele pada kerupuk panggang berpengaruh terhadap menurunnya tingkat kecerahan $\left(L^{*}\right)$, serta meningkatnya warna kemerahan $\left(a^{*}\right)$ dan kekuningan $\left(b^{*}\right)$ secara signifikan $(p<0,05)$. Hal tersebut disebabkan karena pemanasan akan menyebabkan reaksi Mailard yang disebabkan oleh adanya asam

Tabel 4. Hasil analisis warna kerupuk mentah dan panggang dengan menggunakan chromameter Table 4. Result analysis of raw and grilled fish crackers colour using chromameter

\begin{tabular}{|c|c|c|c|}
\hline $\begin{array}{c}\text { Parameter / } \\
\text { Parameters }\end{array}$ & $\begin{array}{c}\text { L1 } \\
(20: 100)\end{array}$ & $\begin{array}{c}\text { L2 } \\
(30: 100)\end{array}$ & $\begin{array}{c}\text { L3 } \\
(40: 100)\end{array}$ \\
\hline \multicolumn{4}{|c|}{ Mentah/Raw fish crackers } \\
\hline$L^{*}$ & $80.94 \pm 1.73^{\mathrm{a}}$ & $83.09 \pm 0.75^{b}$ & $81.8 \pm 0.91^{a}$ \\
\hline$a^{*}$ & $3.62 \pm 0 ; 61^{b}$ & $2.54 \pm 0.22^{a}$ & $2.35 \pm 0.27^{a}$ \\
\hline$b^{*}$ & $17.34 \pm 1.06^{\mathrm{a}}$ & $17.6 \pm 0.52^{\mathrm{a}}$ & $18.64 \pm 0.53^{b}$ \\
\hline \multicolumn{4}{|c|}{ Panggang/Grilled fish crackers } \\
\hline$L^{*}$ & $85.3 \pm 1.01^{\mathrm{c}}$ & $82.62 \pm 0.20^{b}$ & $81.11 \pm 1.55^{\circ}$ \\
\hline$a^{*}$ & $3.12 \pm 0.64^{\mathrm{a}}$ & $5.01 \pm 0.20^{b}$ & $5.69 \pm 0.76^{\mathrm{c}}$ \\
\hline$b^{*}$ & $16.89 \pm 1.44^{\mathrm{a}}$ & $20.37 \pm 0.50^{b}$ & $21.59 \pm 1.80^{b}$ \\
\hline
\end{tabular}

Keterangan/Note: $\mathrm{L}^{*}=$ Kecerahan/Brightness $\mathrm{a}^{*}=$ Kemerahan/Redness, $\quad \mathrm{b}^{*}=$ Kekuningan $/$ Yellowness 
amino, gula dan suhu yang tinggi (Oktavia, 2007). Reaksi Mailard terjadi antara gula pereduksi dengan gugus amina primer dan memberikan produk berwarna kecoklatan.

Semakin banyak proporsi daging lele yang ditambahkan semakin banyak kandungan asam amino kerupuk sehingga produk berwarna lebih coklat yang berpengaruh terhadap menurunnya tingkat kecerahan $\left(\mathrm{L}^{*}\right)$ dan meningkatnya warna kemerahan $\left(\mathrm{a}^{*}\right)$ dan kekuningan $\left(b^{\star}\right)$. Walaupun reaksi ini berpengaruh terhadap menurunnya nilai gizi, tetapi reaksi Maillard tersebut sangat penting dalam pembentukan aroma, flavourdan warna kecoklatan pada kerupuk panggang yang dihasilkan.

\section{Profil Tekstur Kerupuk Panggang Ikan Lele}

Tingkat pengembangan volume kerupuk mengindikasikan tingkat kerenyahan atau tekstur kerupuk. Tekstur kerupuk panggang ikan lele diamati terhadap tingkat kekerasan (hardness) dan kerenyahan (crispiness) yang dapat dilihat pada Tabel 5.

Perlakuan L1 $1_{(20: 100)}$ memiliki nilai kekerasan tertinggi $(8,23 \pm 3,93 \mathrm{~N})$ dan berbeda nyata $(p<0,05)$ dengan perlakuan $L 2_{(30: 100)}(1,13 \pm 3,99 \mathrm{~N})$ dan L3 ${ }_{(4: 100)}(1,28 \pm 2,01 \mathrm{~N})$ yang menghasilkan tingkat kekerasan yang lebih rendah. Hal ini disebabkan semakin banyak proporsi ikan yang diberikan, maka proses gelatinisasi berjalan lebih baik. Daging ikan yang ditambahkan dapat membantu penyediaan air untuk proses gelatinisasi, sehingga pada saat pati dipanaskan di atas suhu gelatinisasinya, pati akan membengkak lebih sempurna. Proses gelatinisasi yang sempurna selain dapat menghasilkan pengembangan yang optimal juga dapat menurunkan tingkat kekerasan dan meningkatkan kerenyahan kerupuk yang dihasilkan (Kyaw et al., 2001, Nurul et al., 2009).

\section{Penampang Mikroskopis Kerupuk Panggang Ikan Lele}

Pengembangan volume dan tekstur berkaitan dengan porositas pada kerupuk panggang ikan lele. Porositas kerupuk panggang dapat diamati secara mikroskopis terhadap permukaan dan penampang melintang kerupuk melalui Scanning Electron Microscopy (SEM) (Gambar 1). Peningkatan proporsi daging ikan lele cenderung dapat meningkatkan ukuran pori-pori udara dengan dinding yang lebih tipis pada kerupuk (Gambar 1-a3). Penambahan ikan akan menyebabkan agregat protein yang terbentuk pada saat denaturasi akan menjebak molekul air sehingga mampu menyempurnakan proses gelatinisasi (Kyaw et al., 1999).

Kondisi tersebut dapat meningkatkan kapasitas pembengkakan pati dan membentuk pori-pori yang lebih besar pada hasil akhir pengembangan kerupuk. Rongga udara ditandai dengan lubang yang dalam dan berwarna hitam. Pada rasio ikan lele dan tepung tapioka sebesar 0: 100 (b/b) dan L1 ${ }_{(20: 100)}$ (Gambar 1a0 dan Gambar 1-a1) dapat dilihat bahwa pori-pori udara yang terbentuk cenderung lebih kecil dan kurang seragam, sedangkan pada perlakuan L2 $\left(_{30-100}\right)$ dan L3 (40-100) (Gambar 1-a2 dan Gambar 1-a3) terdapat pori-pori udara yang berbentuk elips dan bulat dengan ukuran yang relatif lebih besar.

Pada perlakuan L3 ${ }_{(40: 100)}$ (Gambar 1-a3) terdapat area yang besar namun tidak berpori yang diduga merupakan matriks protein. Menurut Cheow, Yu, Howell, Che, dan Muhammad (1999) struktur mikroscopic kerupuk ikan mengandung agregat protein ikan yang ukurannya besar-besar, yang dapat menghambat pengembangan tapioka selama pemanasan sehingga membuat filamen lebih padat. Filamen yang lebih padat tersebut dapat memperhalus

Tabel 5. Profil tekstur kerupuk panggang ikan lele pada berbagai rasio daging ikan lele dan tepung tapioka Table 5. Texture profile of grilled fish cracker at various ratios of fish meat and tapioca flour

\begin{tabular}{lccc}
\hline \multirow{2}{*}{$\begin{array}{c}\text { Parameter/ } \\
\text { Parameters }\end{array}$} & \multicolumn{3}{c}{ Perlakuan /Treatment } \\
\cline { 2 - 4 } & L1 (20:100) & L2 (30:100) & L3 (40-100) \\
\hline Kekerasan/Hardness (Newton) & $8.23 \pm 3.93^{\mathrm{a}}$ & $1.13 \pm 3.99^{\mathrm{b}}$ & $1.28 \pm 2.01^{\mathrm{b}}$ \\
Kerenyahan/Fracturability (Newton) & $14.49 \pm 3.89^{\mathrm{a}}$ & $11.51 \pm 3.28^{\mathrm{a}}$ & $13.1 \pm 2.40^{\mathrm{a}}$ \\
\hline
\end{tabular}



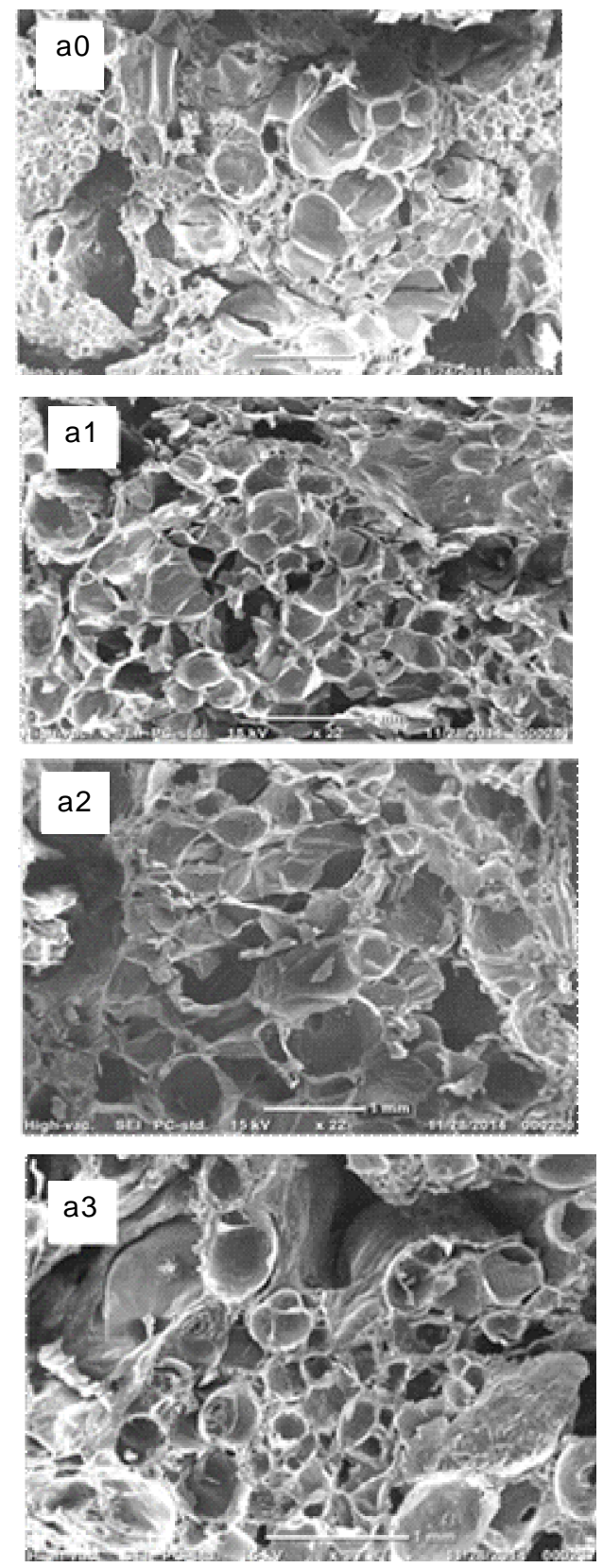
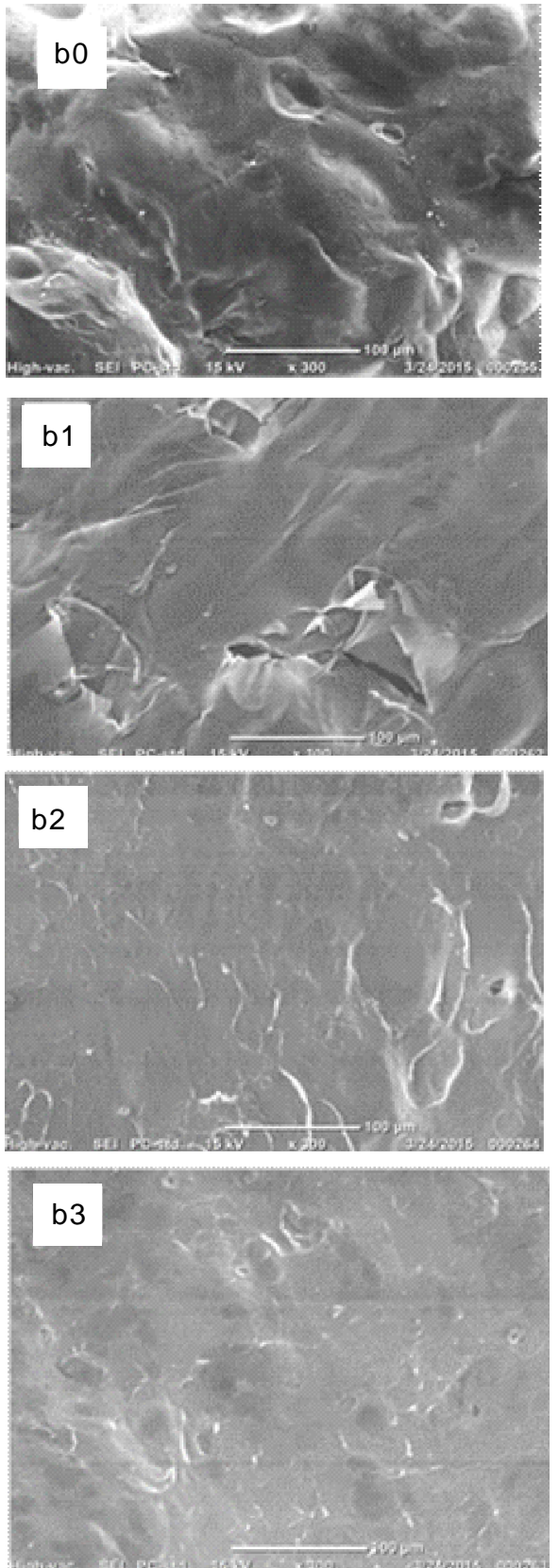

Gambar 1. Mikroskopik kerupuk panggang ikan lele pada berbagai rasio ikan lele dan tepung tapioka. (a) penampang melintang; (b) kenampakan permukaan. Rasio daging ikan lele dan tepung tapioka 0 (0: 100), 1 (20: 100), 2 (30:100) dan 3 (40:100) b/b.

Figure 1 Microscopic grilled catfish fish crackers in various ratios of catfish meat and tapioca flour. (a) the appearance of cross-section (b) the appearance of surface response. Ratio of catfish meat and tapioca flour 0 (0: 100), 1 (20: 100), 2 (30:100) and 3 (40:100) b/b.

permukaan dari kerupuk ikan lele panggang yang dihasilkan.

Terlihat bahwa peningkatan proporsi daging ikan lele (Gambar 1-b0 dan Gambar 1-b3) juga memperhalus permukaan kerupuk panggang ikan lele yang dihasilkan. Pada kerupuk tanpa penambahan ikan lele (Gambar 1-b0) tampak terdapat bagian bergelombang yang muncul pada seluruh permukaan kerupuk dan semakin berkurang seiring dengan peningkatan proporsi daging ikan lele (Gambar 1-b1 dan Gambar 1-b3). 


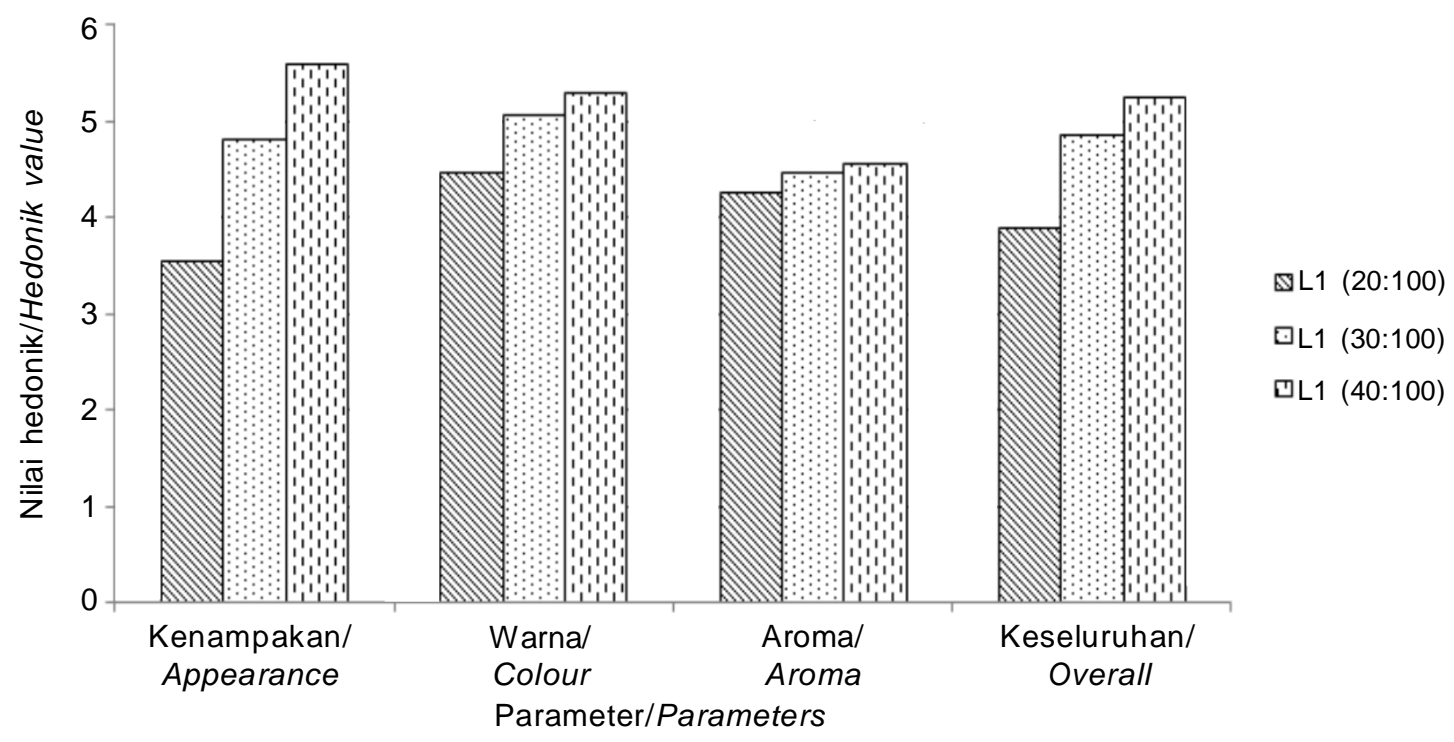

Gambar 2. Nilai hedonik kerupuk ikan lele mentah pada berbagai perlakuan rasio daging ikan lele dan tepung tapioka $(\mathrm{b} / \mathrm{b})$.

Figure 2. Hedonic value of raw catfish crackers at various treatment ratios of catfish meat and tapioca flour $(w / w)$.

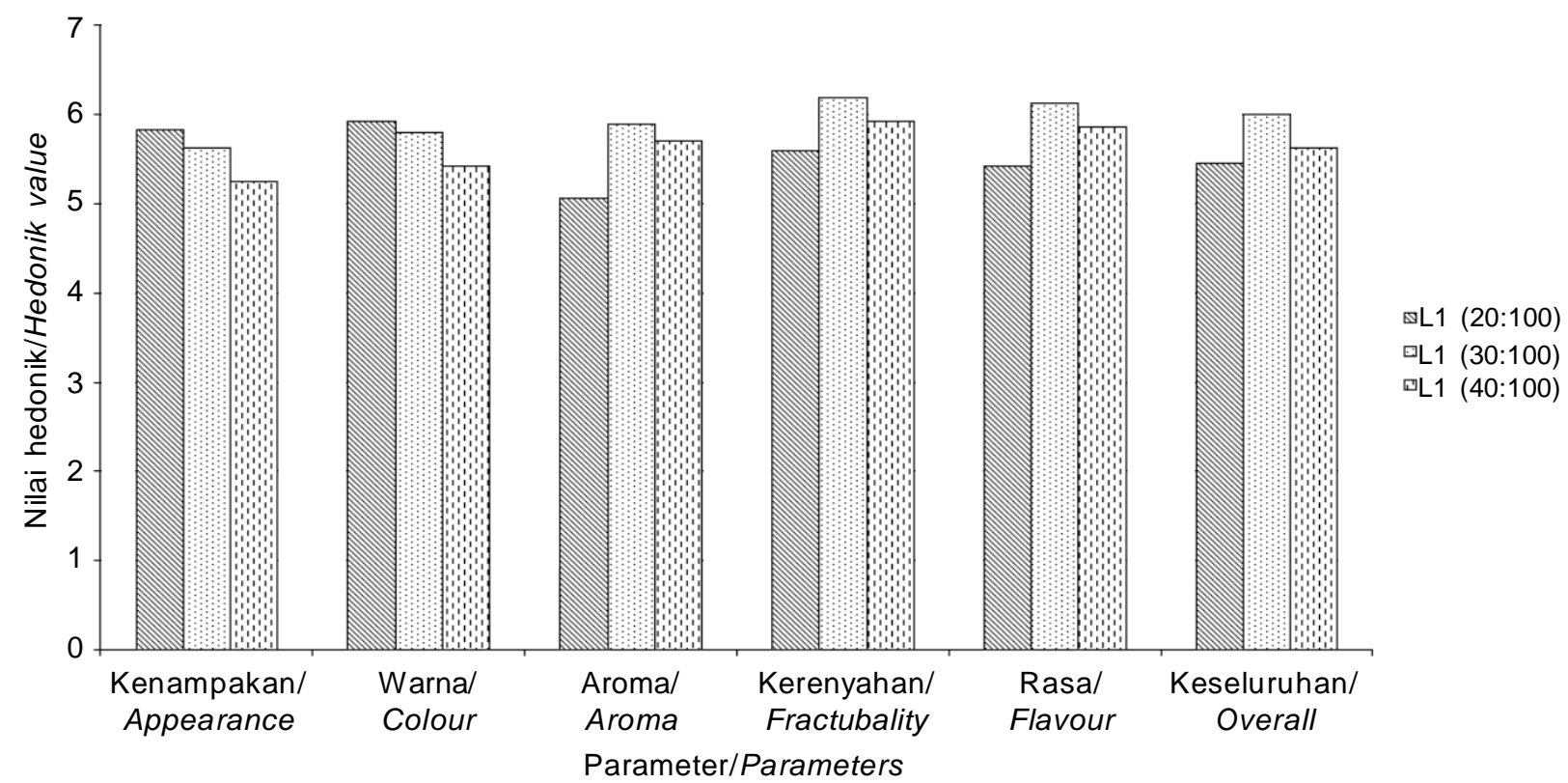

Gambar 3. Nilai hedonik kerupuk panggang ikan lele pada berbagai perlakukan rasio daging ikan lele dumbo dan tepung tapioka $(\mathrm{b} / \mathrm{b})$.

Figure 3. Hedonic value of grilled catfish crackers at various treatment ratios of catfish meat and tapioca flour $(w / w)$.

\section{Sensori Kerupuk Ikan Lele}

Pengamatan sensori kerupuk mentah dilakukan terhadap kesukaan dengan menggunakan uji hedonik. Pengamatan dilakukan terhadap kenampakan, bau, warna, dan tesktur serta kesukaan secara keseluruhan. Untuk kerupuk panggang, selain parameter tersebut di atas, juga diamati terhadap rasa dan kerenyahan. Hasil analisis sensori terhadap kerupuk mentah dan kerupuk panggang dapat dilihat pada Gambar 2 dan 3.

Pada kerupuk mentah semakin besar proporsi ikan yang ditambahkan (perlakuan $\mathrm{L} 2_{40-60}$ ), semakin tinggi penilaian panelis terhadap parameter yang diamati. Panelis memberikan nilai kenampakan $(5,60 \pm 0,89)$, 
warna $(5,30 \pm 0,95)$, bau $(4,57 \pm 1,22)$ dan kesukaan secara keseluruhan $(5,28 \pm 0,81)$ lebih tinggi pada kerupuk dengan perlakuan $\mathrm{L} 3_{(40-100)}$ dibandingkan dengan perlakuan lainnya. Perlakuan $\mathrm{L} 1_{(20: 100)}$ memiliki kenampakan retak-retak, dengan bagian tengah yang agak putih sehingga tampak kurang seragam. Nilai yang diberikan panelis $3,57 \pm 1,45$ antara netral dan agak tidak suka. Hal ini disebabkan karena proses gelatinisasi yang tidak sempurna yang menyebabkan lenjeran tidak matang karena air tidak dapat mencapai bagian tengah lenjeran kerupuk saat proses pengukusan. Kerupuk yang diolah dengan perlakuan ini mempunyai bau yang agak apek $(4,27 \pm 0,94)$, diduga berasal dari bau pati yang belum matang.

Pada kerupuk panggang ikan lele pengamatan yang dilakukan terhadap kenampakan, warna, aroma, kerenyahan, rasa, dan keseluruhan, menunjukkan bahwa perlakuan $L 1_{(20-100)}$ berbeda nyata $(p<0,05)$ dengan perlakuan lainnya, sedangkan perlakuan L2 ${ }_{(30: 100)}$ dan $L 3_{(40: 100)}$ tidak berbeda nyata $(p>0,05)$. Kerupuk panggang ikan lele yang diolah dengan perlakuan $\mathrm{L} 1_{(20-100)}$ mempunyai kenampakan dan warna yang lebih disukai oleh panelis. Sementara untuk aroma, kerenyahan, rasa dan keseluruhan, panelis memberikan nilai yang lebih rendah dibandingkan dengan perlakuan $\mathrm{L} 2_{(30: 100)}$ dan $\mathrm{L} 3_{(40: 100)}$. Kerupuk panggang lele yang diolah dengan perlakuan L1 $1_{(20-100)}$ mempunyai kenampakan dan warna lebih cerah, sementara kerupuk yang diperoleh dari perlakuan $L 2_{(30: 100)}$ dan $L 3_{(40: 100)}$ berwarna sedikit kecoklatan. Hal ini didukung dengan Nilai $L^{*} a^{*} b^{*}$ yang lebih tinggi (Tabel 4). Panelis memberikan nilai aroma terbaik pada perlakuan $\mathrm{L} 2_{(30: 100)}$ yaitu 5,90 (suka) dan L3 ${ }_{(40: 100)} 5,7$ (cenderung ke arah suka), sedangkan untuk perlakuan $\mathrm{L} 1_{(20: 100)}$ panelis memberikan nilai aroma sebesar 5,09 (agak suka). Kesukaan ini dapat dihubungkan dengan aroma yang timbul yang disebabkan reaksi Maillard yang terjadi pada produk, semakin banyak kandungan protein pada produk semakin kuat flavour yang dihasilkan (Drowshak, 1981).

Kerenyahan didefinisikan sebagai pemilikan sifat tekstural pada bahan makanan yang ditunjukkan dengan kecenderungan mudah pecah, bersifat rapuh dan mudah hancur (Wahyuningtyas, Basito \& Atmaka, 2014). Kerenyahan timbul akibat terbentuknya ronggarongga udara pada proses pengembangan pada saat pemanasan (Winarno, 1997).

Panelis memberikan nilai kerenyahan tertinggi pada kerupuk dengan perlakuan L2 ${ }_{(30: 100)}$. Penilaian kerenyahan kerupuk sejalan dengan data kerenyahan/ crispiness dari profil tekstur kerupuk panggang ikan lele dengan menggunakan alat teksture analyzer. Perlakuan L2 $2_{(30: 100)}$ menghasilkan nilai crispiness paling rendah $(11,51 \pm 3,24 \mathrm{~N})$ artinya kerupuk tersebut mudah hancur ketika diberi beban yang lebih ringan dibandingkan dengan perlakuan $L 3_{(40: 100)}(13,06 \pm 2,41$ N) dan $L 1_{(20: 100)}(14,49 \pm 3,29 N)$. Perbedaan tingkat

Tabel 6. Nilai mutu kerupuk panggang dari setiap parameter pengujian Table 6. Quality score of grilled crackers from each parameters test

\begin{tabular}{|c|c|c|c|c|c|c|}
\hline \multirow[b]{2}{*}{$\begin{array}{l}\text { Parameter/ } \\
\text { Parameters }\end{array}$} & \multicolumn{2}{|c|}{ L1 (20:100) } & \multicolumn{2}{|c|}{ L2 (30:100) } & \multicolumn{2}{|c|}{ L3 $(40: 100)$} \\
\hline & $\begin{array}{c}\text { Hasil } \\
\text { Pengujian } \\
\text { /Test } \\
\text { Result }\end{array}$ & $\begin{array}{c}\text { Nilai } \\
\text { Mutu/ } \\
\text { Quality } \\
\text { Value }\end{array}$ & $\begin{array}{c}\text { Hasil } \\
\text { Pengujian } \\
\text { /Test } \\
\text { Result }\end{array}$ & $\begin{array}{c}\text { Nilai } \\
\text { Mutu/ } \\
\text { Quality } \\
\text { Value }\end{array}$ & $\begin{array}{c}\text { Hasil } \\
\text { Pengujian } \\
\text { /Test } \\
\text { Result }\end{array}$ & $\begin{array}{c}\text { Nilai } \\
\text { Mutu/ } \\
\text { Quality } \\
\text { Value }\end{array}$ \\
\hline Kadar protein/Protein (\%) & 3.51 & 1 & 6.79 & 2 & 8.11 & 3 \\
\hline Kadar Lemak/Fat (\%) & 5.01 & 3 & 5.99 & 2 & 7.5 & 1 \\
\hline Kadar Air/Moisture (\%) & 2.55 & 1 & 2.35 & 2 & 2.15 & 3 \\
\hline Pengembangan volume/Volume expansion (\%) & 937.87 & 3 & 886.02 & 3 & 873.02 & 3 \\
\hline Kerenyahan/Crispiness) & 14.49 & 3 & 11.51 & 3 & 13.06 & 3 \\
\hline Warna/Colour & 5.93 & 3 & 5.8 & 3 & 5.43 & 2 \\
\hline Aroma/Aroma & 5.07 & 1 & 5.9 & 2 & 5.7 & 2 \\
\hline Rasa/Taste & 5.43 & 1 & 6.13 & 2 & 5.87 & 2 \\
\hline Kerenyahan(sensori)/Crispiness (sensory) & 5.56 & 1 & 6.2 & 2 & 5.93 & 2 \\
\hline \multirow[t]{2}{*}{ Keseluruhan/Overall } & 5.47 & 1 & 6.00 & 2 & 5.63 & 2 \\
\hline & & 18 & & 23 & & 22 \\
\hline
\end{tabular}


kerenyahan berkaitan erat dengan perbedaan komposisi dari bahan dasarnya terutama komponen amilosa, amilopektin dan kadar protein dalam kerupuk. Dengan meningkatnya konsentrasi daging ikan yang ditambahkan akan berpengaruh terhadap proses gelatinisasi pati dari tapioka yang membentuk gel kerupuk yang matang sempurna. Proses gelatinisasi yang sempurna akan berpengaruh terhadap pengembangan kerupuk yang tinggi pada tahap pemanggangan,sehingga kerupuk dengan volume pengembangan yang tinggi akan memiliki kerenyahan yang tinggi.

Sedangkan menurut Guy (2001) molekul protein pada pemanasan akan membentuk ikatan silang dengan struktur berlapis seperti serat sehingga dapat meningkatkan kegetasan produk. Namun karena pemanasan kerupuk dilakukan dalam bentuk butiran dalam suatu moulderyang panas akan menyebabkan air dari bahan yang mengandung pati dan protein menjadi plastis, produk yang dihasilkan menjadi ringan dengan kualitas fisik dan sensori yang lebih tinggi (Muhtadi, Hariyadi \& Basuki 1987).

Hasil uji hedonik pada parameter rasa menunjukkan panelis memberikan nilai rasa terbaik pada perlakuan $L 2_{(30: 100)}$ dan $L 3_{(40: 100)}$ berturut turut sebesar 6,13 dan 5,86, sedangkan pada perlakuan $\mathrm{L}_{(20: 100)}$ panelis hanya memberikan nilai 5,43 . Penambahan ikan lele menghasilkan krupuk panggang yang lebih disukai oleh panelis karena rasa kerupuk yang lebih gurih dan enak. Rasa gurih ini dapat dikaitkan dengan kandungan protein dan lemak yang lebih tinggi sehingga menghasilkan rasa yang lebih disukai oleh panelis. Semakin banyak ikan lele yang ditambahkan maka akan berpengaruh terhadap rasa kerupuk panggang yang dihasilkan, karena kandungan asam amino isoleusin, leusin, lisin, dan fenilalanin serta glutamat pada lele cukup tinggi (Suryaningrum, Ikasari, \& Murniyati, 2011).

Tingkat kesukaan secara keseluruhan ditentukan oleh beberapa sifat sensori yang bersama sama menentukan kualitas suatu produk. Berdasarkan penilaian secara keseluruhan, panelis memberikan nilai tertinggi terhadap kerupuk panggang lele pada perlakuan $\mathrm{L} 2_{(30: 100)}$ yaitu 6,0 (suka), dibandingkan dengan perlakuan $\mathrm{L} 3_{(40: 100)}$ yaitu sebesar 5,63 dan $\mathrm{L}$ $1_{(20: 100)}$ sebesar 5,46. Secara keseluruhan kerupuk panggang lele yang dihasilkan dengan pemanasan dengan menggunakan moulder yang panas dalam bentuk butiran-butiran dapat menghasilkan struktur kerupuk lebih merata, permukaan lebih halus, tekstur lebih renyah, rasa lebih enak dan bau lebih harum.

Nilai mutu kerupuk dari setiap parameter yang diuji dapat dilihat pada Tabel 6. Berdasarkan parameter yang diamati dan nilai mutu produk yang diperoleh, maka perlakuan terbaik diperoleh pada perlakuan L2 dengan proporsi antara daging lele $30 \%$ dan tapioka $100 \%$.

\section{KESIMPULAN}

Rasio daging ikan lele dan tepung tapioka berpengaruh terhadap kualitas kerupuk panggang ikan lele yang dihasilkan. Semakin besar proporsi daging lele yang digunakan berpengaruh terhadap meningkatnya kadar protein dan kadar lemak. Peningkatan sifat sensori seperti aroma, kerenyahan, dan rasa kerupuk panggang yang dihasilkan mencapai nilai tertinggi pada proporsi lele dengan tapioka $30: 100$. Sebaliknya semakin besar proporsi daging lele yang digunakan berpengaruh terhadap menurunnya kadar air, nilai $a_{w}$, serta kecerahan, kerupuk yang dihasilkan. Berdasarkan parameter yang diamati maka, rasio daging ikan lele dan tepung tapioka sebesar 30:100 (b/b) merupakan rasio perbandingan yang dapat menghasilkan kualitas kerupuk panggang ikan lele terbaik dengan kadar protein sebesar $6,79 \pm 0,54 \%$, kadar lemak sebesar $5,99 \pm 1,04 \%$, kadar air sebesar $2,35 \pm 0,20 \%$, kadar abu sebesar $4,52 \pm 0,12 \%$, kadar karbohidrat sebesar $79,96 \pm 1,46 \%$, pengembangan volume sebesar $886,21 \pm 67,81 \%$, kerenyahan (crispiness) sebesar $11,51 \pm 3,28 \mathrm{~N}$ dan warna dengan nilai tingkat kecerahan $\left(L^{*}\right)$ sebesar 82,62 $\pm 0,20$, kemerahan $\left(a^{*}\right)$ $5,01 \pm 0,20$ dan kekuningan $\left(b^{*}\right) 20,37 \pm 0,50$.

\section{DAFTAR PUSTAKA}

Anonim. (2015). Mengidentifikasi Perbedaan Warna Menggunakan Koordinat $L^{*} a^{*} b^{*}$ PT Amalgam Sejahtera. Jakarta Indonesia.

Astawan, M. (2009). Tentang Lele. Http:// leleepol.wordpress.com. Diakses tanggal 13 Oktober 2015

Badan Standardisasi Nasional (BSN). (1994). SNI. 012713-1999 Kerupuk Ikan. Badan Standarisasi Nasional Indonesia. Jakarta.

Badan Standardisasi Nasional (BSN). (2006). SNI 01.2354 - 2006 Standar Nasional Indonesia. Cara Uji Kimia pada Produk Perikanan.

Cheow, C.S., Yu, S.Y., Howell, N.K., Che M.Y., \& Muhammad, K. (1999). Effect of fish, starch and salt contents on the microstructure and expansion of fish crackers ('Keropok'). Journal of the Science of Food and Agriculture, 79(6), 879-885.

Drowshak, E. (1981). Non enzymatic browning and its effect on protein nutrition. CRC Crit Rev, Food Nutrition, 13, 1-9.

Gomes, M.H., \& Aguillera. J.M. (1983). Changes in the starch fraction during extrusion cooking of corn. $J$ Food Sci, 48, 378-386. 
Guy, R. (2001). Extrusion Cooking: Technologies and Applications. Cambridge: Woodhead Publishing. pp. 111-116.

Hadi, S. (2001). Pola migrasi air adonan kerupuk ikan dalam selongsong selama pemasakan, sifat fisik dan sensoris produk yang dihasilkan Thesis Teknologi Pangan UGM, Yogyakarta.

Haryadi. (1994). Physical characteristics and acceptability of the keropok crackers from different starches. Indonesian Nutrition Progress, 1(1), 23-26.

Huda, N., Ismail, N., Leng, A. L., \& Yee, C. X. (2010). Chemical composition, colour and linear expansion properties of commercial fish cracker. Asean Journal Food Agricultural Industry, 3(5), 473-482

Ibrahim, R., Dewi, E.N., \& Sumardianto, (2003). Evaluation of the thickness and the Linear expansion of fish crackers produced by some cottage industries of Jepara District (Central Java). Journal of Coastal Development, 6(3),145-151.

Ikasari. D., \& Muljanah I. (2014). Pengaruh penambahan rumput laut dan telur terhadap daya kembang dan tingkat kerenyahan kerupuk ikan lele (Clarias batracus) tanpa goreng. Prosiding Seminar Nasional Perikanan UGM Jilid III : pp.303-309 .

Imaningsih, N. (2012). Profil gelatinisasi beberapa formulasi tepung-tepungan untuk pendugaan sifat pemasakan. Penel Gizi Makan, 35(1): 13-22

King, M.A. (2002). Development and sensory acceptability of crackers made from the big-eye fish (Branchydeuterus auritus). Food and Nutrition Bulletin 23(2), 317-340.

Koswara, S. (2009). Pengolahan Aneka Kerupuk. E_bookpangan.com

Kyaw, Z.Y., Yu, S.Y., Cheow, C.S.\& Dzulkifly, M.H. (1999) Effect of steamming time on the linear expansion of fish crackers (keropok). Journal of the Science of Food and Agriculture. 79, 1340-1344.

Kyaw, Z.Y., Yu, S.Y., Cheow, C.S., \& Dzulkifly, M.H. (2001). The effect of pressure cooking on the microstucture and expansion of fish crakers (keropok). Journal of Food Quality. 24, 181-194.

Lovell, T. (2004). The Yellow Fat Problem in Fish Flesh. Aquaculture Magazine, 10(4), 39-40

Muhtadi, T.R., Hariyadi. P., \& Basuki, A. (1987). Teknologi Pangan Ekstruksi. PAU. IPB. Bogor. p. 80-203.

Neiva, C.R.P., Machado, T. M., Tomita, R.Y., Furlan, É. F., Lemos Neto, M. J., \& Bastos, D. H. M. (2011) Fish crackers development from minced fish and starch: An innovative approach to a traditional product. Ciênc. Tecnol. Aliment., Campinas, 31(4), 973-979.

Nurul, H., Boni, I., \& Noryati, I. (2009). The Effect of different ratios of dory fish to tapioca flour on the linear expansion, oil absorption, colour and hardness of fish crackers. International Food Research Journal, 16, 159-165.
Okereke, A.N., \& Onunkwo, D.N. (2014). Acceptance of fish crackers produced from filapia and catfish. Journal of Environmental Science, Toxicology and Food Technology (IOSR-JESTFT). 8, 45-48.

Oktavia. D.A. (2007). Kajian SNI 01-2886-2000. Makanan ekstrudat. Jurnal Standardisasi, 9(1): 1-9.

Peranginangin, R., Fawzya, Y.N., Sugiyono \& Muljanah, I. (1997). Food additives and effect of thickeness on fish crackers quality. In Kuang H. K., Kim, L.L. and Yong, L. P. (eds.). Proceeding of the seminar on the advances in fish processing technology in Southeast Asia in relation to quality management. $\mathrm{p}$ 106-114. Singapore. MFRD-SEAFDEC.

Sartika, R.A.D. (2009) Pengaruh suhu dan lama proses menggoreng (deep frying) terhadap pembentukan asam lemak trans. Makara, Sains, 13(1), 23-28.

Setiawan, D.W., Sulistiyati. T.D., \& Suprayitno E. (2013). Pemanfaatan residu daging ikan gabus (Ophiocephalus striatus) dalam pembuatan kerupuk ikan beralbumin Hpi Student Journal, 1(1), 21-32.

Siswantoro. (2009). Perubahan volume dan kadar air kerupuk selama penggorengan dengan menggunakan pasir. Prosiding Semnas Dies Natalis Pertanian Universitas Jendral Sudirman. Purwokerto.

Suryaningrum, T. D., Ikasari, D., \& Murniyati. (2011). Pengolahan Aneka Produk Olahan Lele. Penerbit Penebar Swadaya. $54 \mathrm{p}$.

Suryaningrum, T. D., Peranginangin, R., Irianto, H. E., Muljanah, I., \& Syamdidi (2013). Laporan teknis peningkatan nilai tambah dan diversifikasi produk olahan ikan air tawar. Balai Besar Penelitian dan Pengembangan Pengolahan Produk dan Bioteknologi Kelautan dan Perikanan. Jakarta.

Taewee, T. K. (2011) Mini Review Cracker "Keropok" : A review on factors influencing expansion. International Food Research Journal, 18(3), 855-866.

Winarno, F. G. (1997). Kimia Pangan dan Gizi. Gramedia Pustaka Utama. Jakarta.

Wahyuningtyas, N., Basito, \& Atmaka, W. (2014) Kajian karakteristik fisikokimia dan sensoris kerupuk berbahan baku tepung terigu, tepung tapioka dan tepung pisang kepok kuning. Jurnal Teknosains Pangan, 3(2), 76-85.

Wijaya, F. D. (2011) Pengaruh proporsi terigu dan tapioka terhadap sifat fisikokimia dan organoleptik kerupuk bandeng. Skripsi, Fakultas Teknologi Pertanian UNIKA Surabaya.

Yulistiani, Jariah, R., \& Siswoyo, D. (2004). Pembuatan kerupuk ikan belut dengan perbedaan proporsi ikan dan tepung tapioka dan lama pengukusan. Jurnal Penelitian IImu IImu Teknik, 2(2), 1 - 9.

Yu, S. Y. (1991). Effect of fish and flour ratio on fish crackers 'keropok'. ASEAN Food Journal, 6(1), 36.

Yu, S. Y. (1993). Effect of rice starch on the linear expansion of fish crackers (keropok). Tropical Science, 33(3), 319-321. 


\section{LAMPIRAN I/ANNEXI}

LAMPIRAN 1. Lembar Uji Sensori/Annex I. Sensory Scoresheets

a) Lembar uji hedonik kerupuk mentah/Hedonic test scoresheets of raw crackers

\section{UJI HEDONIK/HEDONIC TEST}

Nama panelis/Panelist's name

Tanggal Pengujian/Date of test

Produk/Product
/Jam/Time.

\section{: KERUPUK MENTAH/RAW CRACKERS}

Instruksi : Dihadapan saudara terdapat sampel berkode. Nilailah pernyataan anda dan berikan komentar terhadap sampel tersebut berdasarkan penilaian saudara dengan nilai sebagai berikut :

Instruction: you are presented with three coded samples. Please write down your score and give any comments based on following scores :

1 : Sangat Tidak Suka/Extremely Dislike

2 : Tidak Suka/Moderately Dislike

3 : Agak Tidak Suka/Slightly Dislike

4 : Netral/Neither Like nor Dislike

5 : Agak Suka/Slightly Like

6 : Suka/Moderately Like

7 : Sangat Suka/Extremely Like

\begin{tabular}{|c|c|c|c|c|}
\hline \multirow{2}{*}{$\begin{array}{c}\text { KODE SAMPEL/ } \\
\text { SAMPLE CODE }\end{array}$} & \multicolumn{3}{|c|}{ PARAMETER/PARAMETERS } & \multirow{2}{*}{$\begin{array}{c}\text { KESELURUHAN/ } \\
\text { OVERALL }\end{array}$} \\
\cline { 2 - 5 } & $\begin{array}{c}\text { KENAMPAKAN/ } \\
\text { APPEARANCE }\end{array}$ & WARNA/COLOR & BAU/ODOR & \\
\hline 65393 & & & & \\
\hline 16545 & & & & \\
\hline 38112 & & & & \\
\hline
\end{tabular}

Komentar/Comment: 


\section{LAMPIRAN I/ANNEX I}

LAMPIRAN I. Lembar Uji Sensori/Annex I. Sensory Scoresheets

b) Lembar uji hedonik kerupuk ikan lele panggang / Hedonic test scoresheets of grilled catfish crackers

\section{UJI HEDONIK/HEDONIC TEST}

Nama panelis/Panelist's name Tanggal Pengujian/Date of test Produk /Jam/Time

Instruksi : Dihadapan saudara terdapat sampel berkode. Nilailah pernyataan anda dan berikan komentar terhadap sampel tersebut berdasarkan penilaian saudara dengan nilai sebagai berikut :

Instruction: you are presented with three coded samples. Please write down your score and give any comments based on following scores :

1 : Sangat Tidak Suka/Extremely Dislike

2 : Tidak Suka/Moderately Dislike

3 : Agak Tidak Suka/Slightly Dislike

4 : Netral/Like nor Dislike

5 : Agak Suka/Slightly Like

6 : Suka/Moderately Like

7 : Sangat Suka/Extremely Like

\begin{tabular}{|c|c|c|c|c|c|c|}
\hline \multirow{2}{*}{$\begin{array}{l}\text { KODE SAMPEL/ } \\
\text { SAMPLE CODE }\end{array}$} & \multicolumn{5}{|c|}{ PARAMETER/PARAMETERS } & \multirow{2}{*}{$\begin{array}{c}\text { KESELURUHAN/ } \\
\text { OVERALL }\end{array}$} \\
\hline & $\begin{array}{l}\text { KENAMPAKAN/ } \\
\text { APPEARANCE }\end{array}$ & $\begin{array}{l}\text { WARNA } \\
\text { COLOR }\end{array}$ & $\begin{array}{c}\text { AROMA } \\
\text { ODOR }\end{array}$ & $\begin{array}{l}\text { KERENYAHAN/ } \\
\text { CRISPINESS }\end{array}$ & $\begin{array}{l}\text { RASA/ } \\
\text { TASTE }\end{array}$ & \\
\hline \multicolumn{7}{|l|}{65393} \\
\hline \multicolumn{7}{|l|}{16545} \\
\hline 38112 & & & & & & \\
\hline
\end{tabular}

Komentar/Comment: 
JPB Kelautan dan Perikanan Vol. 11 No. 1 Tahun $2016: 25-40$ 